\title{
God Bless America
}

\author{
Tamari Cheishvili \\ Independent Scholar, NY, USA
}

America I have given you nothing but talent.

You gave me all...

America, I write my own poem and I am in a state of Euphoria...

They bother me with their goddamn mood and biased ideas.

America, they are not angelic and when will you unmask them?

when will you end up their mockery?

America, sometimes I look at myself from the grave

and the invisible is laughing at me

America, you discovered me many times

Do miracles again

What are U waiting for?

Don't tell me to wait for Godot,

No!

How many times

I have walked these rainy streets on the Manhattan

with soaking memories and wet thoughts,

in the silence...

Time flies

Avoid chiming of ebony...

This is my premature burial.

America, let's begin new life

$\mathrm{U}$ know my hidden gifts

$\mathrm{U}$ know that my mind quotes ideas all the time

America, sometimes I don't feel well

and I don't blame U—this is me playing hide and seek

I just feel reborn anew...

sometimes marbles cannot control my aspirations.

Let's make the universe stop being weird,

nasty, cruel, vicious, malicious, vindictive, heartless, callous...

America, "if I don't scold evil now, how to make kindness"

but if the evil didn't exist, we would be in paradise ...

I hear Bells of Edgar

I want to "howl" like Allen Ginsburg

and I HOWL WHOLE a HOLE of dark sides of the human being...

O! It's so extraordinary!

America I write my own poem and I am in a state of euphoria. 